\title{
STRATEGIC INTELLIGENCE OF AN ORGANIZATION AMID UNCERTAINTY
}

\author{
LAZAR D. GITELMAN, MIKHAIL V. KOZHEVNIKOV \& GALINA S. CHEBOTAREVA \\ Academic Department of Energy and Industrial Enterprises Management Systems, \\ Ural Federal University, Russia.
}

\begin{abstract}
The paper deals with the formation and development of strategic intelligence, a fundamentally new management mechanism in organizations that provides information and analytical support for making anticipatory decisions and the company's preparedness for unpredictable challenges of the future. The paper systematizes academic approaches in terms of distinctive features and classification criteria of strategic intelligence, formulates its key objectives in the course of digital transformation, and gives the criteria for assessing its level in companies. It is shown that the establishment of strategic intelligence requires the introduction of specialized management systems, such as anticipatory management, and the formation of relevant competencies based on anticipatory learning. An anticipatory management model is proposed that takes into account weak signals for timely and adequate response to emerging threats. The power engineering industry has been used as an example for demonstrating the given model's capabilities to create standard algorithms for making anticipatory decisions in difficult situations. The paper also defines the role of strategic intelligence in the process of digital transformation and the transformation of organizations into self-learning ones.

Keywords: digital transformation, proactive management, proactive training, self-learning organization, strategic intelligence, uncertainty, weak signals.
\end{abstract}

\section{INTRODUCTION}

Given the context of rapid scientific and technical progress with the assumed transition to technological singularity, only those market participants who will be able to identify the upcoming changes sooner than their competitors, and to define the future shape of their industry and organization, can secure sustainable development [1-5]. Uncertainty accompanying the vision of the future forms the probabilistic nature of the intended trajectory of development and various risk constraints [6-7]. At the same time, ensuring preparedness for anticipatory response to the necessary changes and implementing them before the competitors does become not just the most important advantage but the essential condition for the survival of an organization or a company [8-10]. Such preparedness is achieved by means of using the managerial and industrial design that is flexible and adaptable to new circumstances, and the relevant unique competencies [8-10].

The said imperative is implemented when a fundamentally different development management model is introduced. This model is characterized by the focus on innovations and involves the following $[3,8,10]$ :

- Regular monitoring and foresight of changes in the global environment.

- Analytical system of early identification of challenges, threats, and new opportunities as per weak signals.

- Strategic process filled with other content and methods of management.

The vision of the future with the specification required for practical purposes and the preparation for its implementation require a huge amount of new knowledge, a variety of information, and innovative solutions. Past experience and intuition-based thereon lose their 
significant role in management as they form a basis for traditional governance acting as a response to the deviation that has already happened and unable to prevent negative situations. The intellectual capacity of the administrative solutions will have to be radically improved within a very short time, and new management staff, systems, methods, and technologies will be needed for this purpose. However, the main thing is the business environment, in which knowledge, abilities to generate ideas and to use analytical data, and business initiative will become valuable.

\section{THEORETICAL BACKGROUND, BASIC CONCEPTS, AND TERMINOLOGY}

Strategic intelligence is a systematic and continuous process of exploring trends and the market environment with the use of powerful analytical systems that ensure the generation of knowledge and digital tools for making long-term decisions and the organization's preparedness for the unpredictable challenges of the future. With regard to management, strategic intelligence performs the function of detecting, identifying, and solving problems that go beyond the past experience, and which the organization is going to face in the future.

Strategic intelligence implies a coordinated combination of the following procedures:

1. Research as a tool for early response to threats and opportunities of the external environment (taking into account signals characterizing future threats taken in conjunction with the significant events of the present).

2. Comprehensive analysis of changes in consumer preferences.

3. Development of awareness (including the exchange of knowledge, experience, and projects) through the establishment of global communication networks.

4. Transformation of employees into active developers and users of innovations and strategic solutions.

In practice, there has been significant development of one of the most important components of strategic intelligence. This component is called business intelligence (BI) and describes a system of business analysis designed to support and to make managerial decisions. The term was coined in 1989 by Howard Dresner to describe 'concepts and methods to improve business decision-making by using fact-based support systems' [11]. BI pools together processes, technologies, and tools required to convert data into information, information into knowledge, and knowledge into facts that govern the operation of a successful business company. It comprises data repositories, business analytics methods, and knowledge management with the account of the following interests of different stakeholders: (1) report generation; (2) online analytical processing (OLAP); (3) data mining; (4) process mining; (5) corporate performance management, e.g. enterprise resource planning (ERP) and customer relationship management (CRM); (6) benchmarking; (7) text mining; (8) predictive and descriptive analytics; (9) scenario generation; and (10) data business design into convenient, interactive images.

BI software design makes it possible to compile quick reports, to analyze, and to submit the required data. The BI platform supports a wide range of management functions, including economic planning, budgeting, forecasting, real-time business monitoring, and scenarios for the future, advanced business analytics with the account of stakeholders' interests. These technologies make it possible to process large amounts of data in order to discover and to create new strategic business opportunities. 
The emphasis is placed on traditional financial and economic indicators (e.g. profit and return on assets) when assessing the impact of BI on the economic efficiency of the company. However, it becomes particularly interesting to analyze the following non-financial benefits: development of innovative abilities and competencies; building effective communications within the organization; and reducing time for creating innovative solutions.

The quality of the company's relationships with the stakeholders (reputation and leadership, consumer satisfaction, staff motivation, and justification of innovative solutions) is a separate category of non-financial indicators [12].

A summary of academic publications reveals the following strategic intelligence functions which are of most importance to the activity of organizations:

- Prediction of fluctuations in the external environment, in the behavior of key stakeholders, or in consumer preferences, and of shifts in the competitive field for the proactive adaptation of an organization to changes and for improving its agility level [13-15].

- Information and analytical support for making anticipatory decisions, preparation of strategic reporting with the use of advanced visualization tools [16-17].

- Development of the general strategic culture of an organization, of its creative environment, encouraging open communications and distributed leadership [18-19].

- Adjustment of strategic planning and corporate policy in accordance with potential changes in the area of industrial regulation [15]. For example, the strategic intelligence of an electric utility can be used to synchronize its development plans with the prospects of the emergence of new priorities in the regional energy policy, in industrial programs of digital transformation, and in the national energy strategy.

It is important to distinguish between strategic intelligence, tactical intelligence, and operational intelligence. These types of the organization's intelligence have different process orientation, scale of the analyzed context, and tools (Fig. 1, Table 1). However, it is necessary to emphasize that strategic intelligence cannot exist without advanced operational and tactical intelligence [20]. A highly developed information infrastructure, which defines the analytical potential of the organization, is necessary for strategic intelligence to function. This potential is characterized by the so-called information width (implying the analytics' horizontal coverage of the internal processes - from routine processes to strategizing) and depth (implying the ability of analytical systems to react to trends, strong and weak signals in the core and adjacent markets, in the industries and inter-industry complexes, and finally in the global environment as a whole).

An important feature of strategic intelligence is the possibility to quantify the level of its development through the following: (a) 'prediction horizon' (the longer the prediction period, the higher the strategic intelligence); (b) depth and complexity of the changes; (c) extent of decision-making digitization (provision of digital data) and the use of predictive analytics while making strategic decisions; and (d) number of employees involved in interdisciplinary projects related to the introduction of digital technology.

Strategic intelligence may be used in firms and in organizations not only for them to achieve their market objectives but also for the purposes of ensuring the security of states [21]. In this case, it is based on powerful analytical systems supported by supercomputers and on the operation of multi-disciplinary teams bringing together experts from the areas of geopolitics, international economic activity, ecology, power engineering, systems engineering, defense, and others. 


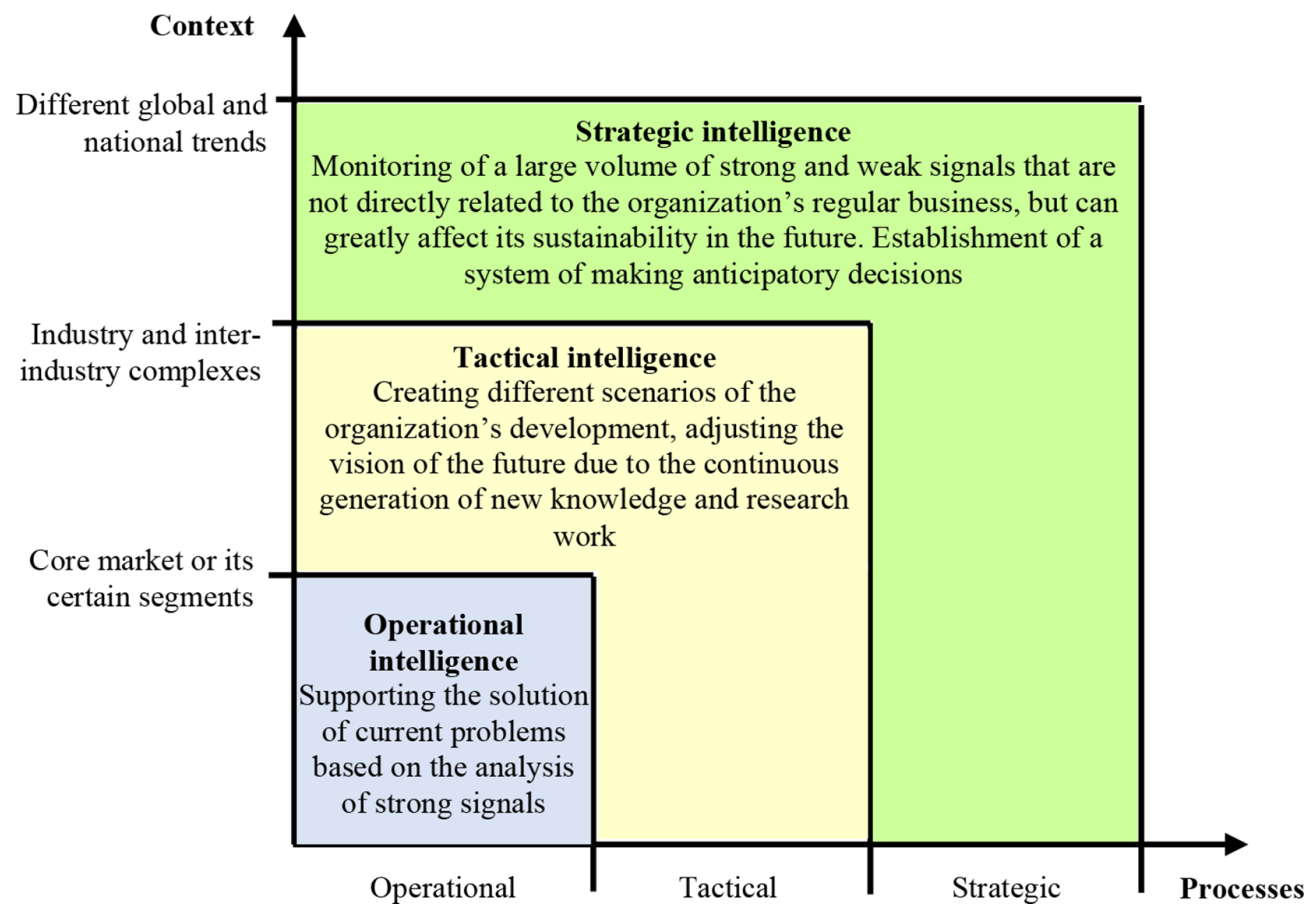

Figure 1: Focuses of different types of organization's intelligence.

Table 1: Principal differences between strategic and tactical intelligence.

\begin{tabular}{lll}
\hline Criterion & Strategic intelligence (SI) & Tactical intelligence (TI) \\
\hline \multirow{2}{*}{$\begin{array}{ll}\text { Main } \\
\text { purpose }\end{array}$} & $\begin{array}{l}\text { To provide the users with the information } \\
\text { that helps to put forward new broad initia- } \\
\text { tives and to develop an outpacing strategy } \\
\text { based on the analysis of trends within the } \\
\text { external environment }\end{array}$ & $\begin{array}{l}\text { To provide users with } \\
\text { the information for the } \\
\text { implementation of existing } \\
\text { initiatives based on the analy- } \\
\text { sis of the current situation }\end{array}$ \\
$\begin{array}{l}\text { The time } \\
\text { horizon } \\
\text { being } \\
\text { explored }\end{array}$ & $\begin{array}{l}\text { SI provides a glimpse into the future, thus } \\
\text { allowing organization to see emerging } \\
\text { trends and patterns and the range of pos- } \\
\text { sible outcomes; it helps the organization to } \\
\text { adjust its policy before a critical situation } \\
\text { arises }\end{array}$ & $\begin{array}{l}\text { TI works 'here and now' } \\
\text { thus allowing organization to } \\
\text { benefit from current advan- } \\
\text { tages }\end{array}$ \\
Users & $\begin{array}{l}\text { Persons involved in making strategic deci- } \\
\text { sions; traditionally, top managers }\end{array}$ & $\begin{array}{l}\text { Experts with the } \\
\text { responsibility in a specific } \\
\text { field of activity }\end{array}$ \\
& & High \\
$\begin{array}{l}\text { Data } \\
\text { sharpening }\end{array}$ & Moderate &
\end{tabular}




\section{INFORMATION INFRASTRUCTURE AS A BASIS FOR STRATEGIC INTELLIGENCE}

Companies that already have effective strategic intelligence or wish to develop it build their own information infrastructure to be able to respond to emerging trends well in advance and to be ready to use new opportunities. Their management should assimilate various types and sources of business information, such as market, political, technological, environmental, and social, in order to visualize the future. The efficiency of how the company handles information depends on three key capabilities:

- Development of information processes for clear identification of information that is deemed strategic.

- Introduction of technologies which ensure effective information logistics.

- Building a corporate culture which encourages the exchange of information and knowledge.

However, in order to be ready to respond rapidly to unpredictable changes in the future, managers also need to develop their own research competencies, as decision-making requires a solid basis of continuously updated analytical materials and strategic foresights.

Michael Maccoby [22] proposed the following system of abilities which would enable the management aspiring to leadership to form strategic intelligence:

- Foresight - the ability to anticipate trends that can pose a threat to an organization or provide opportunities.

- Visioning - the ability to conceptualize an ideal future state and to involve others in its implementation.

- Systems thinking - the ability to perceive, synthesize, and integrate elements that function as a whole in order to achieve a common goal.

- Motivating - the ability to motivate different people to work together to implement the vision that has been created.

- Partnering - the ability to create strategic alliances with individuals, groups of people, and organizations.

The existence of blind spots - areas in which managers do not notice important information or do not understand it - is the biggest risk for strategic intelligence. These areas include, for instance, incorrect definition of the industry's boundaries, inability to identify emerging market preferences, and underestimation of competitors [23]. However, there are many ways to reduce the risks arising from the existence of blind spots. For example, it is recommended to answer the following questions for that purpose.

What are the current trends? The top managers should make sure that they understand global changes in the areas of demographics, state regulation, and consumer markets projected for the next five or ten years.

Where does the majority of industry innovations come from? How will the forthcoming developments affect the company and its business segment? The top managers should look at the adjacent markets beyond their industry, as this is where the competition will emerge in the future.

What modern technologies may lead to new forms of much-needed products or services? The same basic technologies may be used in completely different ways while developing a new product and increasing its added value. 
Table 2: Organizations with high and low information infrastructure maturity [25].

\begin{tabular}{|c|c|c|}
\hline Criteria & Maturity level - high & Maturity level - low \\
\hline $\begin{array}{l}\text { Predominant } \\
\text { role of IT } \\
\text { technologies }\end{array}$ & Strategic & Operational \\
\hline Corporate culture & $\begin{array}{l}\text { Proactivity, trust, openness to in- } \\
\text { novations are encouraged }\end{array}$ & $\begin{array}{l}\text { Reactive decision-making, } \\
\text { skepticism, resistance to } \\
\text { changes }\end{array}$ \\
\hline $\begin{array}{l}\text { Defining man- } \\
\text { agement attention }\end{array}$ & Openness to new ideas & $\begin{array}{l}\text { Control of processes and } \\
\text { operations }\end{array}$ \\
\hline $\begin{array}{l}\text { Attitude toward } \\
\text { training }\end{array}$ & $\begin{array}{l}\text { Consistency of training, mistakes } \\
\text { being structured to create the 'expe- } \\
\text { rience base' }\end{array}$ & $\begin{array}{l}\text { Training is only necessary to } \\
\text { know how to properly perform } \\
\text { functions; analysis of mistakes } \\
\text { being a waste of time }\end{array}$ \\
\hline Information flows & $\begin{array}{l}\text { Possess high speed and are inde- } \\
\text { pendent on the organizational } \\
\text { structure. Information is provided on } \\
\text { time in the required quantity and } \\
\text { quality }\end{array}$ & $\begin{array}{l}\text { Greatly controlled and } \\
\text { protected. There is always a } \\
\text { lack of information, and it is } \\
\text { provided with a delay }\end{array}$ \\
\hline
\end{tabular}

What are the needs of the contemporary customers? Which of these needs are satisfied, and which are not? In this regard, the analysts should constantly study the 'area', to understand the consumers' behavior and to develop the scenarios of product expansion.

What are the company's basic abilities and how can they be effectively used? It is necessary to always search for areas of further business expansion and diversification [24].

Only organizations with a high level of information infrastructure maturity, as indicated in Table 2, can carry out continuous development of strategic intelligence. Thus, the information infrastructure is a core mechanism for strategic intelligence support.

\section{FOCUS ON ANTICIPATORY MANAGEMENT}

Strategic intelligence describes the organization's ability to foresee the future and to be proactive. Its role increases dramatically during large-scale reforms aimed at improving the organization's sustainability in the future: e.g. it is the strategic intelligence that comes to the fore and becomes one of the core competencies during the digital transformation. In turn, the establishment of strategic intelligence requires the introduction of specialized management systems such as anticipatory management and readiness to master the relevant competencies. Figure 2 presents the key elements of anticipatory management; Fig. 3 shows how strategic intelligence propped by the anticipatory management system is involved in addressing the tasks of digital transformation.

The industry level of the anticipatory management model translates into a state policy (strategy) which defines the scientific and technical development of the given industry and its markets, mechanisms for managing reliability, safety and environmental friendliness of production, methods for regulation of mergers and acquisitions, and prices of products (for monopolists). What makes this policy different is its prominent innovative nature and its 


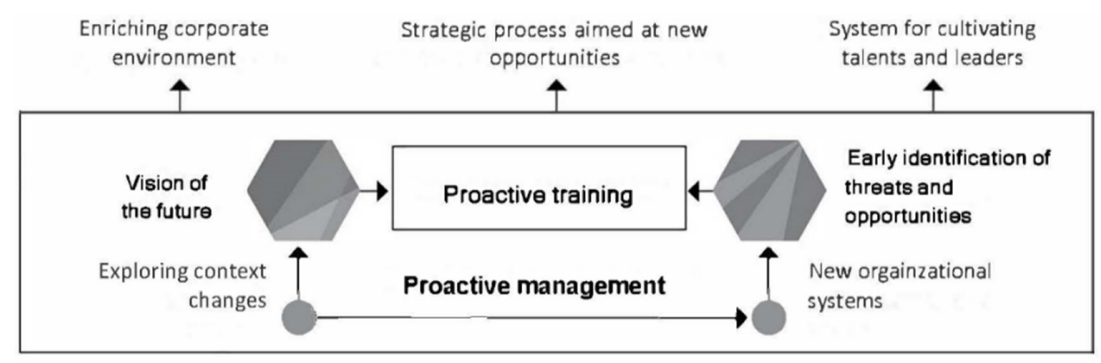

Figure 2: Anticipatory management model.

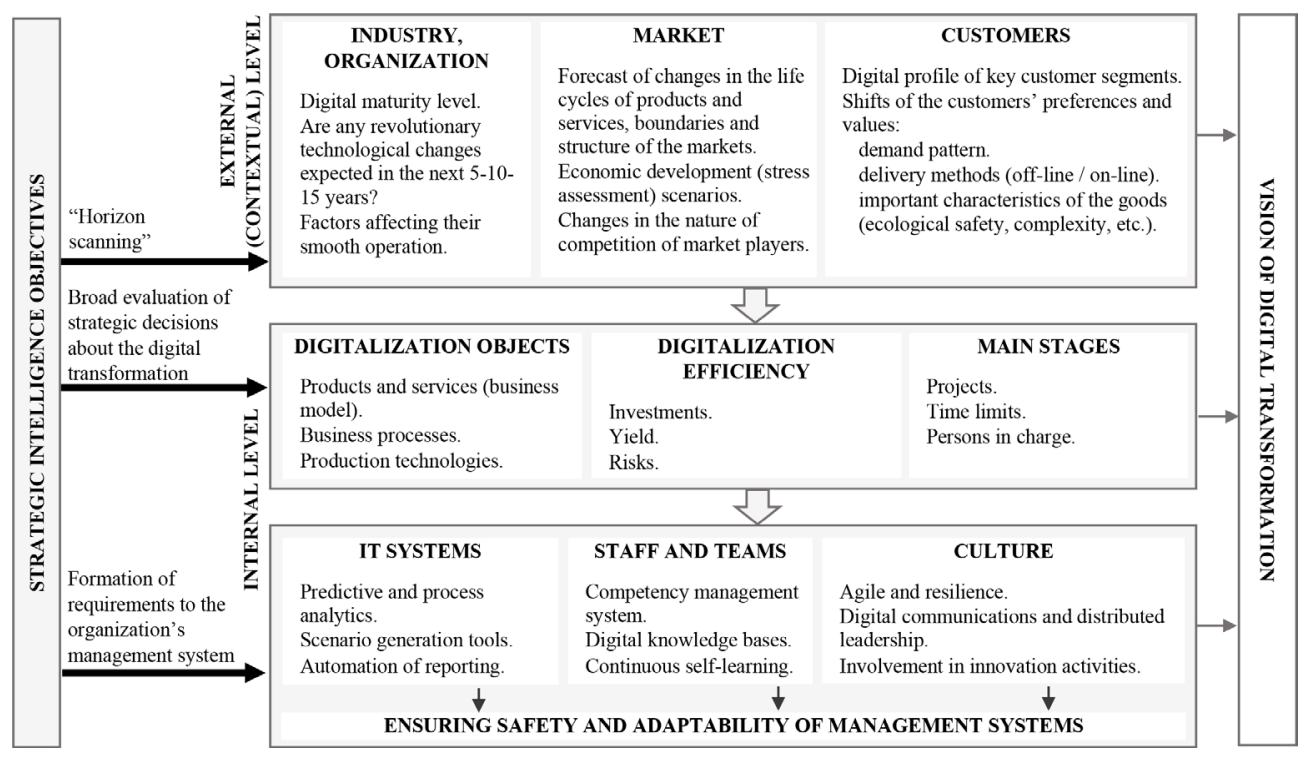

Figure 3: Strategic intelligence objectives during digital transformation.

capability to produce probability estimates and to take into account possible threats and limitations.

At the corporate level and the level of production facility, the model produces a strategy for comprehensive support and building up functional efficiency on all aspects of operation, the dependence on external factors being minimized. Particular attention should be paid to the quality and effectiveness of using resources of all kinds: equipment, fuel and power, finances and investments, and human resources. This work should be done regularly based on the continuous monitoring of the complex state of the facilities and those achievements in the scientific and technological progress which should be initiated to update production.

Thus, the concept of anticipatory management is the methodological basis for the development management model; in addition, it should provide for the sustainability of development and at the same time to increase the strategic flexibility of the organization. 


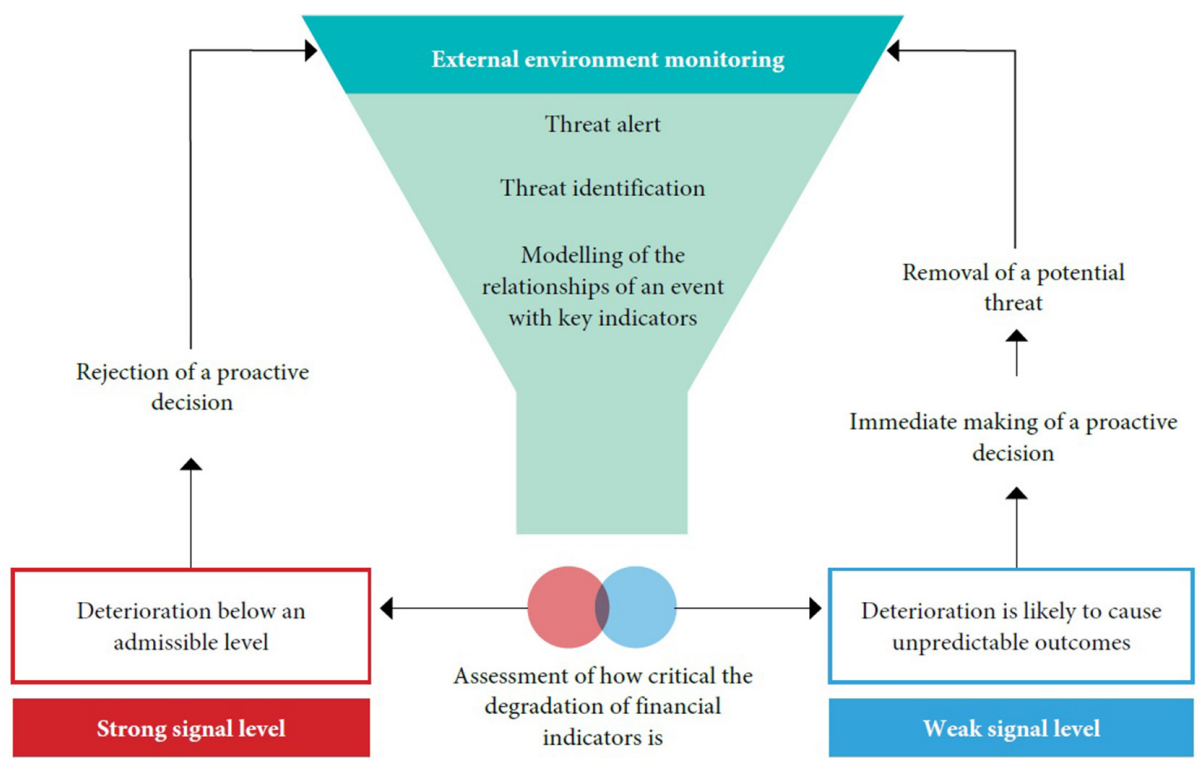

Figure 4: Anticipatory management process structure.

4.1 Proactive management model with the account of weak signals

Solving the management issue of weak signals requires a well-established surveillance system sensitive to warning information (Fig. 4); managers and staff should be prepared to embrace changes and take risk in solving new problems [26]. The problem of understanding the information contained in the signal is the most serious challenge of processing weak signals. This is due to the fact that managers' mental models are conservative and resistant to change.

Following this scheme allows one to promptly and adequately respond to emerging threats. However, monitoring is usually carried out in the strategic focus area of a company and does not preclude the risk of missing weak signals that appear in the periphery. In the power engineering industry, e.g. new technologies that become available to consumers may have a crucial impact on their businesses.

This refers to such technologies as smart power consumption metering systems, power accumulators, applications facilitating energy transactions between customers without the need to connect to market infrastructure. Accordingly, their demand for electric power decreases or increases sharply. Such changes occur everywhere, but only a few of them are actually captured by monitoring.

The application of anticipatory management technique by means of developing standard algorithms for decision-making in the power engineering industry enabled the creation of a methodological basis for anticipatory management that is shown in Table 3.

\subsection{Anticipatory training that shapes strategic intelligence}

Anticipatory management implies continuous anticipatory training. This term refers to an organized process of forming knowledge and competencies to solve future problems that meet global trends and national development programs. The purpose of anticipatory training 
Table 3: Examples of anticipatory management algorithms.

\begin{tabular}{|c|c|c|c|}
\hline Parameter & $\begin{array}{l}\text { Wholesale generat- } \\
\text { ing company (TPP } \\
\text { included) }\end{array}$ & $\begin{array}{l}\text { Territorial generating } \\
\text { company }\end{array}$ & $\begin{array}{l}\text { Grid (distribution) } \\
\text { company }\end{array}$ \\
\hline $\begin{array}{l}\text { Monitoring } \\
\text { facility }\end{array}$ & $\begin{array}{l}\text { Competitive position- } \\
\text { ing of the power } \\
\text { company in the } \\
\text { wholesale market }\end{array}$ & $\begin{array}{l}\text { Balance between power } \\
\text { and capacity (demand and } \\
\text { supply) in the region (or } \\
\text { electric power system) }\end{array}$ & $\begin{array}{l}\text { Regulatory institution pricing } \\
\text { policy }\end{array}$ \\
\hline Threat alert & $\begin{array}{l}\text { Possibility of the } \\
\text { power company rat- } \\
\text { ing being decreased } \\
\text { in terms of fuel } \\
\text { component costs due } \\
\text { to the emergence of } \\
\text { a more efficient gen- } \\
\text { erator in the market }\end{array}$ & $\begin{array}{l}\text { Expected disparities in the } \\
\text { power balance due to the } \\
\text { uncertainty of demand }\end{array}$ & $\begin{array}{l}\text { Expected price limit for } \\
\text { the transmission of power } \\
\text { (capacity) }\end{array}$ \\
\hline $\begin{array}{l}\text { Threat identi- } \\
\text { fication }\end{array}$ & $\begin{array}{l}\text { - Event probability } \\
\text { estimate, \% } \\
\text { Expected value of } \\
\text { TPP load reduction } \\
\text { by the market } \\
\text { generator, MW } \\
\text { - Event remoteness } \\
\text { time, months }\end{array}$ & $\begin{array}{l}\text { - Event probability esti- } \\
\text { mate, \% } \\
\text { - Balance deficiency (re- } \\
\text { dundancy) value, MW } \\
\text { Event remoteness time, } \\
\text { years } \\
\text { Event duration - pe- } \\
\text { riod of time prior to the } \\
\text { increase in demand or to } \\
\text { the launch of new power } \\
\text { capacities, as per the } \\
\text { original plan, years }\end{array}$ & $\begin{array}{l}\text { - Probability of the decision } \\
\text { being made by a regulatory } \\
\text { institution, \% } \\
\text { - Relative price reduction } \\
\text { (as compared to the current } \\
\text { regulation method), \% } \\
\text { - Period of proactive } \\
\text { measures (time before the } \\
\text { restrictions are introduced), } \\
\text { months or years } \\
\text { - Restriction duration (esti- } \\
\text { mated), years }\end{array}$ \\
\hline $\begin{array}{l}\text { Consequence } \\
\text { assessment } \\
\text { for a power } \\
\text { company }\end{array}$ & \multicolumn{3}{|c|}{$\begin{array}{l}\text { - Net present value reduction } \\
\text { - Reduction of future return on assets, } \%\end{array}$} \\
\hline $\begin{array}{l}\text { Options of } \\
\text { proactive } \\
\text { solutions }\end{array}$ & $\begin{array}{l}\text { - Technical and } \\
\text { organizational } \\
\text { measures to reduce } \\
\text { specific fuel } \\
\text { consumption levels } \\
\text { - Search for } \\
\text { suppliers offering } \\
\text { lower fuel prices } \\
\text { - Access to the } \\
\text { market of free } \\
\text { contracts }\end{array}$ & $\begin{array}{l}\text { Development of demand } \\
\text { management programs } \\
\text { for the consumers } \\
\text { - Emergency launch of } \\
\text { small power producing } \\
\text { facilities (distributed } \\
\text { generation establish- } \\
\text { ment) } \\
\text { - Offering idle capacities } \\
\text { to a grid operator as a } \\
\text { system reserve } \\
\text { Use of temporary } \\
\text { reduced rates for the } \\
\text { consumers with } \\
\text { connection delays }\end{array}$ & $\begin{array}{l}\text { Technical and organiza- } \\
\text { tional measures to reduce } \\
\text { the constant part of the } \\
\text { costs and to decrease } \\
\text { technical and commercial } \\
\text { losses in networks } \\
\text { - Managing consumers' } \\
\text { loads in order to increase } \\
\text { the transmission capacity } \\
\text { of the existing power grid } \\
\text { - Contacting the consumers } \\
\text { on the issue of reactive } \\
\text { power (load) compensation } \\
\text { - Building small-scale } \\
\text { generation plants }\end{array}$ \\
\hline
\end{tabular}


of experts is for them to acquire knowledge for working in engineering and technical, business, and socio-humanistic systems that might be established in the foreseeable future, based on new principles and functioning in the external environment characterized by high turbulence and uncertainty [27], [28].

For this paper, it is important to emphasize that nowadays organizations are experiencing great demand for the comprehensive analytical support for business processes and solutions, which is only possible if they possess a certain level of digital maturity and high potential of strategic intelligence. The level of strategic intelligence, its update, and growth, in turn, depend on the intensity and efficiency of the research process in the organization and its partners, as well as on the timely use of new knowledge in training. It is this condition that actually ensures the relevance of the anticipatory nature of training. This is why our anticipatory training programs incorporate a distinctive research component, which is based on continuous context analysis of trends, challenges, threats, and opportunities that exist in the external environment and structural transformations happening in the economy. Such analysis is performed by students and/or staff members of companies with guidance from instructors. This exercise equips them with tools for early verification of corporate projects under development in accordance with anticipated trends.

\section{CONCLUSIONS}

Strategic intelligence plays a special role for the purposes of increasing sustainability and competitiveness of companies during the period of growing uncertainty of the external environment. It allows one to take into account not only the signals indicating future threats but also opportunities which will emerge in the near future. Strategic intelligence is based on digital tools for analyzing changes in consumer preferences, the transformation of employees into active developers and users of strategic solutions, and the establishment of communication networks aimed at accelerating the exchange of knowledge, experience, and projects.

Strategic intelligence is particularly important during digital transformation as it acts as a radar scanning the periphery and helps to set, most impartially, the priorities in the context of new product and investment areas, in making difficult decisions that require multi-criterion assessment of feasibility and consequences of certain actions.

The effective functioning of strategic intelligence in an organization largely depends on the availability of anticipatory training systems in it and on the ability of such systems to turn into self-learning ones. It is a company which is cultivating a continuous exchange of ideas, knowledge, and information and is continuously building up the competencies of its staff and teams, that is able to quickly adapt to market changes. Without this prerequisite, strategic intelligence would not be able to fulfil its main purpose implying foresight and readiness for the future, and risks becoming a set of costly intellectual support tools with vague functions and user-specific orientation.

\section{ACKNOWLEDGMENT}

The work was supported by Act 211 Government of the Russian Federation, contract No. 02.A03.21.0006.

\section{REFERENCES}

[1] Gitelman, L., Magaril, E., Kozhevnikov, M. \& Rada, E.C., Rational behavior of an enterprise in the energy market in a circular economy. Resources, 8(2), p. 73, 2019. https://doi.org/10.3390/resources 8020073 
[2] Su, Y., Si, H., Chen, J. \& Wu, G., Promoting the sustainable development of the recycling market of construction and demolition waste: A stakeholder game perspective. Journal of Cleaner Production, 277, p. 122281, 2020. https://doi.org/10.1016/j. jclepro.2020.122281

[3] Schoneveld, G.C., Sustainable business models for inclusive growth: Towards a conceptual foundation of inclusive business. Journal of Cleaner Production, 277, p. 124062, 2020. https://doi.org/10.1016/j.jclepro.2020.124062

[4] Gitelman, L.D., Silbermann, V.A., Kozhevnikov, M.V., Makarov, A.Y. \& Sandler, D.G., Energy engineering and consulting: New challenges and reality. International Journal of Energy Production and Management, 5(3), pp. 272-284, 2020. https://doi. org/10.2495/eq-v5-n3-272-284

[5] Gitelman, L.D., Kozhevnikov, M.V. \& Adam, L.A., Sustainable energy for smart city. International Journal of Energy Production and Management, 4(4), pp. 343-353, 2019. https://doi.org/10.2495/eq-v4-n4-343-353

[6] Chebotareva, G., Strielkowski, W. \& Streimikiene, D., Risk assessment in renewable energy projects: A case of Russia. Journal of Cleaner Production, 269, p. 122110, 2020. https://doi.org/10.1016/j.jclepro.2020.122110

[7] Chebotareva, G.S., Risk assessment of renewable energies: Global exposure. International Journal of Energy Production and Management, 4(2), pp. 145-157, 2019. https:// doi.org/10.2495/eq-v4-n2-145-157

[8] Wang, N., Ren, S., Liu, Y., Yang, M., Wang, J. \& Huisingh, D., An active preventive maintenance approach of complex equipment based on a novel product-service system operation mode. Journal of Cleaner Production, 277, p. 123365, 2020. https://doi. org/10.1016/j.jclepro.2020.123365

[9] Schmitz, W.I., Schmitz, M., Canha, L.N. \& Garcia, V.J., Proactive home energy storage management system to severe weather scenarios. Applied Energy, 279, p. 115797, 2020. https://doi.org/10.1016/j.apenergy.2020.115797

[10] Severo, E.A., Sbardelotto, B., de Guimarães, J.C.F. \& de Vasconcelos, C.R.M., Project management and innovation practices: backgrounds of the sustainable competitive advantage in Southern Brazil enterprises. Production Planning and Control, 31(15), pp. 1276-1290, 2020. https://doi.org/10.1080/09537287.2019.1702734

[11] Rouhani, S., Asgari, S. \& Mirhosseini, S.V., Review study: Business intelligence concepts and approaches. American Journal of Scientific Research, 50, pp. 62-75, 2012.

[12] Kuznetsov, S.Y., Business intelligence as a tool for innovative enterprise management [Biznes-intellekt kak instrument upravleniya innovacionnym predpriyatiem]. Strategic decisions and risk management [Strategicheskie resheniya i risk-menedzhment], 4, pp. 78-83, 2012.

[13] Vedder, R.G., Vanecek, M.T., Guynes, C.S. \& Cappel, J.J., CEO and CIO perspectives on competitive intelligence. Communications of the ACM, 42(8), pp. 108-116, 1999. https://doi.org/10.1145/310930.310982

[14] Johanson, A., What is Competitive Intelligence, http://www.aurorawde.com/ Accessed on: 10 May 2020.

[15] Al-Zu'bi, H.A., Aspects of strategic intelligence and its role in achieving organizational agility: An empirical investigation. International Journal of Academic Research in Business and Social Sciences, 6(4), pp. 233-241, 2016. https://doi.org/10.6007/ijarbss/ v6-i4/2101 
[16] Baars, H. \& Kemper, H.-G., Management support with structured and unstructured data - An integrated business intelligence framework. Information Systems Management, 25(2), pp. 132-148, 2008. https://doi.org/10.1080/10580530801941058

[17] Lönnqvist, A. \& Pirttimäki, V., The measurement of business intelligence. Information Systems Management, 23(1), pp. 32-40, 2006. https://doi.org/10.1201/1078.10580530 /45769.23.1.20061201/91770.4

[18] Rouhani, S., Asgari, S. \& Mirhosseini, S.Y., Review study: Business intelligence concepts and approaches. American Journal of Scientific Research, 50, pp. 62-75, 2012. https://doi.org/10.1038/scientificamerican02021884-74e

[19] Maccoby, M., Only the brainiest succeed. Research Technology Management, 44(5), pp. 1-4, 2004.

[20] Freedman, M., Creating Strategic Excellence, http://www.kepner_tregoe.com $\backslash$ Accessed on: 10 May 2020.

[21] Akhgar, B. \& Yates, S., (eds.), Strategic Intelligence Management: National Security Imperatives and Information and Communications Technologies, Elsevier: Oxford, 2013.

[22] Maccoby, M., (ed.), Strategic Intelligence, Conceptual Tools for Leading Change, Oxford University Press, 2015.

[23] Jones, J., (ed.), Design Methods [Metody proektirovaniya], Mir [Mir]: Moscow, 1986.

[24] Büchel,B.,Fromblind spotstostrategicintelligence.Ensuring growthoptionsareexploited, https://www.imd.org/research-knowledge/articles/from-blind-spots-to-strategicintelligence/ Accessed on: 10 May 2020.

[25] Gileva, T.A., Digital maturity of the enterprise: Methods of assessment and management. Bulletin USPTU. Science, Education, Economy. Series Economy, 1(27), pp. 38-52, 2019. https://doi.org/10.17122/2541-8904-2019-1-27-38-52

[26] Gitelman, L.D., Gavrilova, T.B., Gitelman, L.M. \& Kozhevnikov, M.V., Proactive management in the power industry: Tool support. International Journal of Sustainable Development and Planning, 12(8), pp. 1359-1369, 2017. https://doi.org/10.2495/sdpv12-n8-1359-1369

[27] Gitelman, L.D., Kozhevnikov, M.V. \& Ryzhuk, O.B., Advance management education for power-engineering and industry of the future. Sustainability, 11(21), p. 5930, 2019. https://doi.org/10.3390/su11215930

[28] Senge, P., (ed.), Fifth Discipline: The Art and Practice of Self-learning Organizations [Pyataya disciplina: iskusstvo i praktika samoobuchayushchejsya organizacii], OlympBusiness [Olimp-Biznes], 1999. 